\title{
KONSTRUKSI MAKNA KUALITAS HIDUP SEHAT (Studi Fenomenologi pada Anggota Komunitas Herbalife Klub Sehat Ersanddi Jakarta)
}

\author{
${ }^{1}$ Endang Susanti, ${ }^{2}$ Nur Kholisoh \\ ${ }^{1}$ Institut Ilmu Sosial dan Manajemen STIAMI, \\ $1 \& 2$ Universitas Mercu Buana \\ Program Studi Magister Ilmu Komunikasi \\ Email: ${ }^{1}$ endsantiers@ gmail.com, ${ }^{2}$ kholisoh.nur@gmail.com
}

Keywords:

Meaning,

Healthy life style,

Symbolic interaction,

Phenomenology

This study was intended to get a comprehensive picture of meaning construction in building the quality of healthy life. This research used symbolic interaction theory of George Herbert Mead. The study relied on phenomenological approach under a paradigm of constructivism using interpretative analysis. In-depth interview, observation, and documentation study were conducted to collect data. This study found that the motives of Herbalife community health club Ersanddi members to participate in a healthy life program because they wanted to lose weight and to be physically fit. The meaning of healthy lifestyle for them is to be able to enjoy their life and worship to the Creator without any obstacles. The meaning of healthy life to the members of Herbalife community health club of Ersanddi was influenced by their environment namely significant others and reference groups.
\end{abstract}

\section{Pendahuluan}

Kesehatan merupakan aspek terpenting dalam kehidupan dan mendukung berjalannya aktivitas secara optimal. Kesehatan diartikan sebagai kondisi fisik,mental dan sosial yang terbebas dari gangguan penyakit sehingga aktivitas yang berjalan di dalamnya dapat terjadi secara optimal. Untuk mencapai standar kesehatan yang baik maka diperlukan adanya proses pengelolaan lingkungan sekitar dan aktivitas harian yang tercermin dalam gaya hidup sehat. Gaya hidup sehat merupakan gaya hidup masyarakat yang menjunjung tinggi aspek-aspek kesehatan seperti pengelolaan kebersihan dan kesehatan lingkungan, menjaga kebugaran fisik dan psikis dan pemberian asupan nutrisi yang cukup, sehingga tercapai standar kesehatan yang baik.

Selama lebih dari 30 tahun terakhir, kecenderungan kelebihan berat badan meningkat tiga kali lipat. Lebih dari separuh penduduk di Indonesia secara aktif berusaha mengendalikan berat badannya. Dewasa ini semakin banyak orang yang memiliki jumlah penduduk tertinggi dengan masalah berat badan berlebih. Kombinasi dari pola makan yang buruk dan minimnya aktivitas fisik adalah penyebab utama dari kelebihan berat badan atau kegemukan. Dari perkiraan 210 juta penduduk Indonesia pada tahun 2000, jumlah penduduk yang overweight diperkirakan mencapai 76.7 juta (17.5\%) dan pasien obesitas berjumlah lebih dari 9.8 juta (4.7\%). Berdasarkan data tersebut, dapat disimpulkan bahwa overweight dan obesitas di Indonesia telah menjadi masalah besar yang memerlukan penanganan secara serius (www.rssuyoto.com, 2017)

Meningkatnya angka overweight dan obesitas secara global di seluruh dunia saat ini dianggap sebagai akibat dari beberapa faktor, antara lain peningkatan dalam konsumsi makanan padat energi tinggi lemak dan gula namun rendah dalam kandungan vitamin, mineral dan mikronutrien lain. Selain itu, hal tersebut diakibatkan adanya suatu trend penurunan aktivitas fisik yang disebabkan oleh gaya hidup (sedentary), pekerjaan, perubahan model transportasi dan peningkatan urbanisasi. Overweight dan obesitas yang dibiarkan memiliki dampak kesehatan yang cukup serius. Resiko menderita penyakit degeneratif akan meningkat secara progresif seiring dengan peningkatan Indeks Massa Tubuh (IMT). IMT yang meningkat merupakan faktor resiko utama penyakit-penyakit kronis seperti 
Kardiovaskular (penyakit jantung dan stroke), diabetes (yang saat ini sudah menjadi epidemi global), gangguan otot dan tulang (paling sering adalah osteoarthritis) dan beberapa penyakit keganasan. Pada anak, angka obesitas juga semakin meningkat dari tahun ke tahun baik di negara maju maupun di negara sedang berkembang. Obesitas pada anak juga beresiko tinggi menjadi obesitas pada usia dewasa dan berpotensi menimbulkan penyakit degeneratif di kemudian hari.

Menurut data WHO, $70 \%$ kematian disebabkan oleh berbagai penyakit : jantung, diabetes, stroke, dan kanker. Separuh orang dari jumlah tersebut memiliki pola makan yang buruk. Pola makan modern pemicu utama timbulnya penyakit degeneratif. pola makan modern tidak sesuai dengan pengertian pola hidup sehat, terlalu banyak karbohidrat dan lemak serta kekurangan mengonsumsi serat serta sering memakan makanan yang cepat saji yang mengandung pengawet, kalori kosong, penyedap rasa, dan lemak. Selain itu kebiasaan ngemil yang berlebihan, merokok juga dapat memiliki dampak buruk bagi kesehatan. Karena di dalam rokok mengandung zat kimia berbahaya bagi kesehatan tubuh.

Masyarakat di seluruh dunia mulai menyadari pentingnya menjaga kesehatan. Berbagai cara dilakukan agar mendapat kesehatan yang optimal. Menurut World Health Organization, health is a state of complete physical, mental and social well-being and not merely the absence of diseases or infirmity. Pola makan yang seimbang akan memberikan kecukupan nutrisi yang dibutuhkan oleh tubuh, sehingga tubuh akan berfungsi dengan baik. Sayangnya hal ini menjadi tantangan sulit bagi sebagian besar orang Amerika dan masyarakat Indonesia pada umumnya.

Melihat kondisi dan gaya hidup yang selama ini penulis lihat di dalam kehidupan sehari-hari, di mana makanan produksi Amerika Serikat seperti burger, fried chicken dan hotdog yang di negara produsennya sendiri dianggap makanan sampah (junk food), di negara kita malah dijadikan trend. Bahan-bahan kimia sintesis yang jauh dari sifat alami justru dijadikan makanan favorit.

Perkembangan Fenenomena hidup sehat sangat berkaitan dengan konsep diri sesorang dalam menghargai dirinya sendiri dan juga keinginan untuk dihargai oleh masyarakat. Pembentukan tubuh ideal melalui perilaku gaya hidup sehat dan olahraga bisa dikatakan pemberitahuan informasi yang coba disampaikan komunitas hidup sehat Herbalife pada masyarakat mengenai pentingnya hidup sehat. Pergeseran konsep diri terlihat bagaimana mereka mempersentasikan diri baik secara tatap muka maupun melalui media sosial.

Tujuan hidup sehat dan pembentukan tubuh ideal tidak lepas dari membangun kepercayaan diri dan adanya pergeseran nilai dalam pembentukan citra seseorang yang dapat dinilai dari gaya hidup sehat yang terapkan sehari-hari. Pada tatanan kehidupan sosial dan lingkungan gaya hidup sehat dan tubuh ideal telah menjadi cara pandang baru masyarakat untuk menilai seorang individu dari kepedulian terhadap penampilan, bentuk tubuh proposional maupun kepribadian seseorang. Adanya penghargaan yang lebih dari masyarakat ketika melihat seseorang yang memiliki kebiasaan hidup sehat menjadikan lebih menarik perhatiaan dan lebih menyalurkan sebuah kekuatan positif terutama mengarah kepada pola hidup sehat.

Berdasarkan konsep dasar teori interaksi simbolik menurut George Herbert Mead, seseorang memerlukan bantuan orang lain dalam memahami ataupun menilai dirinya sendiri. Oleh sebab itu, peran orang lain juga dibutuhkan untuk menilai seseorang dalam bertindak atau ketika melakukan sesuatu. Konsep diri merupakan suatu bagian yang penting dalam setiap pembicaraan tentang kepribadian manusia. Konsep diri setiap orang dapat membedakan orang tersebut dengan orang lain, sehingga konsep diri menjadi sesuatu yang unik pada manusia. Sebagai manusia, kita tidak hanya melakukan persepsi terhadap orang lain, tetapi juga mempersepsi diri kita sendiri. Saat mempersepsi diri sendiri itu, diri kita menjadi subjek dan objek persepsi sekaligus (Sumarwan: 2011:63).

Gaya hidup merupakan salah satu aspek yang esensial di era modern ini. Gaya hidup merupakan gambaran bagi setiap orang yang mengenakannya dan menggambarkan seberapa besar prilaku seseorang di dalam masyarakat. Selain itu, gaya hidup juga dapat diartikan sebagai suatu seni yang dibudayakan oleh setiap orang. Gaya hidup yang dijalani dapat menentukan kualitas hidup dan kesehatan tubuh. Seseorang yang memiliki gaya hidup yang positif dan pola hidup yang sehat cenderung memiliki kualitas hidup yang lebih memadai, begitu juga sebaliknya. Gaya hidup merupakan salah satu indikator kualitas hidup seseorang. Seseorang yang memiliki gaya hidup sehat akan menjalankan kehidupannya dengan memperhatikan faktor-faktor yang mempengaruhi kesehatan seperti makanan, pikiran, kebiasaan olahraga, dan lingkungan yang sehat. Hal ini akan menyebabkan 
tingkat kesehatan seseorang menjadi baik. Kesehatan yang baik menjadikan kualitas hidup seseorang meningkat (Anne, 2010).

Gaya hidup sehat adalah pilihan sederhana yang sangat tepat untuk dijalankan. Gaya hidup sehat adalah sehat dengan pola makan, pikiran, kebiasaan dan lingkungan yang sehat. Sehat dalam arti kata mendasar adalah segala hal yang kita kerjakan memberikan hasil yang baik dan positif. Hidup sehat adalah hidup dengan fisik, psikologi, lingkungan dan finansial yang sehat, cukup, dan baik. Menurut tabloid gaya hidup sehat, hidup sehat itu adalah cara menyelenggarakan proses kehidupan sehingga memberikan kondisi positif bagi diri sendiri dan lingkungan (Mister, 2008).

Dalam gaya hidup sehat, seseorang dapat diubah dengan cara memberdayakan individu agar merubah gaya hidupnya, merubahnya bukan pada si individu saja, tetapi juga merubah lingkungan sosial dan kondisi kehidupan yang memengaruhi pola perilakunya. Perubahan bisa terjadi setiap saat, dan merupakan proses yang dinamik serta tidak dapat dielakkan. Berubah berarti beranjak dari keadaan yang semula. Tanpa berubah tidak ada pertumbuhan dan tidak ada dorongan. Setiap orang dapat memberikan perubahan pada orang lain. Merubah orang lain bisa bersifat implisit dan eksplisit atau bersifat tertutup dan terbuka.

Komunikasi komunitas mempunyai pengaruh terhadap perilaku atau gaya hidup baru yang dipilih seseorang dan digunakan para anggotanya dan lingkungan sekitar. Menjalin kerjasama dengan komunitas lebih ampuh (efektif) dalam merubah perilaku seseorang dibandingkan berkomunikasi dengan cara biasa. Tak dapat dipungkiri komunitas memiliki peran yang signifikan dalam upaya membangun kepercayaan dan kesadaran bersama untuk mencapai tujuan tertentu secara bersamasama.

Suatu komunitas tentu sangat membutuhkan komunikasi demi berkembang dan majunya komunitas tersebut. Seorang ketua dalam suatu komunitas harus memiliki kemampuan berkomunikasi yang baik agar dapat memimpin anggotanya. Pengertian komunitas menurut Kertajaya (2008) adalah sekelompok orang yang saling peduli satu sama lain lebih dari yang seharusnya, di mana dalam sebuah komunitas terjadi relasi pribadi yang erat antar para anggota komunitas tersebut karena adanya kesamaan interest atau value (digilib.unila.ac.id, 2017).

Anggota Herbalife di Jakarta mulai membentuk komunitas-komunitas dan membangun klubklub yang dijadikan sebagai tempat pelaksanaan proses penurunan berat badan (diet) sehat dengan Herbalife dan kegiatan-kegiatan seputar pelaksanaan strategi dalam meningkatkan kualitas perilaku hidup sehat. Klub Sehat Ersanddi merupakan salah satu klub yang terletak di Jakarta Barat. Klub Sehat Ersanddi merupakan salah satu komunitas yang di dalamnya terdiri dari individu-individu yang memiliki tujuan yang sama yakni sama-sama ingin hidup sehat. Klub ini merupakan tempat/sarana bagi orang-orang tersebut melakukan aktivitas dan sharing dalam meningkatkan kualitas perilaku hidup sehat yang dibentuk dan dikelola oleh anggota Herbalife serta sebagai penyedia produk-produk Herbalife.

Mengacu pada fenomena tersebut, peneliti tertarik untuk menggali lebih dalam bagaimana kontruksi makna kualitas hidup sehat dalam komunitas Herbalife Klub Sehat Ersanddi Jakarta. Peneliti menggunakan studi fenomenologi untuk menggali pengalaman dan konstruksi makna para informan.

\section{Tinjauan Pustaka}

\subsection{Teori Interaksi Simbolik}

Teori interaksi simbolik (symbolic interactionism) memfokuskan perhatiannya pada cara-cara yang digunakan manusia untuk membentuk makna dan struktur masyarakat melalui percakapan. Interaksi simbolis pada awalnya merupakan suatu gerakan pemikian dalam ilmu sosiologi yang di bangun oleh George Herbert Mead, dan karyanya kemudian menjadi inti dari dari aliran pemikiran yang dinamakan Chicago School. Menurut Morissan (2013: 224-225) interaksi simbolis mendasarkan gagasannya atas enam hal yaitu: (1). Manusia membuat keputusan dan bertindak pada situasi yang dihadapinya sesuai dengan pengertian subjektifnya, (2). Kehidupan sosial merupakan proses interaksi, kehidupan sosial bukanlah struktur atau bersifat structural dan karena itu akan terus berubah, (3). Manusia memahami pengalamannya melalui makna dari symbol yang digunakan dilingkungan terdekatnya (primary group), dan bahasa merupakan bagian yang sangat penting dalam kehidupan social, (4). Dunia terdiri dari berbagai objek sosial yang memiliki nama dan makna yang ditentukan secara social, (5). Manusia mendasarkan tindakannya atas interpretasi mereka, dengan 
mempertimbangkan dan mendefinisikan objek-objek dan tindakan yang relevan pada situasi saat itu, dan (6). Diri seseorang adalah objek signifikan dan sebagaimana objek sosial lainnya diri didefinisikan melalui interaksi sosial dengan orang lain.

Mead adalah pemikir yang sangat penting dalam sejarah interaksionisme simbolik (Joas, 2001) dan bukunya yang berjudul Mind, Self dan Society adalah karya tunggal yang amat penting dalam tradisi itu. Mead megambil tiga konsep kritis yang diperlukan dan saling memengaruhi satu sama lain untuk menyusun sebuah teori interaksionisme simbolik. Dengan demikian, pikiran manusia (mind), dan interaksi sosial (diri/self) digunakan untuk menginterpretasikan dan memediasi masyarakat (society) (Elvinaro, 2007:136).

\subsubsection{Pikiran (Mind)}

Pikiran yang didefinisikan Mead sebagai proses percakapan seseorang dengan dirinya sendiri, tidak ditemukan dalam diri individu; pikiran adalah fenomena sosial. Pikiran muncul dan berkembang dalam proses sosial dan merupakan bagian integral dari proses sosial.

\subsubsection{Diri (Self)}

Mead mencoba memberikan arti secara behavioristis tentang diri. "Diri" adalah di mana orang memberikan tanggapan terhadap apa yang ia tujukan kepada orang lain dan di mana tanggapannya sendiri menjadi bagian dari tindakannya, di mana ia tak hanya mendengarkan dirinya sendiri, tetapi juga merespon dirinya sendiri, berbicara dan menjawab dirinya sendiri sebagaimana orang lain menjawab kepada dirinya, sehingga kita mempunyai perilaku di mana individu menjadi objek untuk dirinya"

Diri adalah aspek lain dari proses sosial menyeluruh di mana individu adalah bagiannya. Dengan kata lain, untuk mencapai diri sempurna, orang harus menjadi anggota komunitas dan ditunjukan dengan kesamaan sikapnya dengan sikap komunitas. Penerimaan peran orang lain yang digeneralisir tak hanya penting bagi diri, tetapi juga penting bagi perkembangan aktivitas kelompok terorganisir. Kelompok menghendaki agar individu mengatur aktivitas mereka sesuai dengan sikap orang lain yang digeneralisasi. Orang lain yang digeneralisir ini juga mencerminkan kecenderungan Mead memprioritaskan kehidupan sosial, karena melalui generalisasi orang lainlah kelompok mempengaruhi perilaku individu. (George Ritzer, 2007: 284).

\subsubsection{Masyarakat (Society)}

Pada tingkat paling umum, Mead menggunakan istilah masyarakat (society) yang berarti proses sosial tanpa henti yang mendahului pikiran dan diri. Masyarakat penting perannya dalam membentuk pikiran dan diri. Pada tingkat kemasyarakatan yang lebih khusus. Mead mempunyai sejumlah pemikiran tentang pranata sosial (sosial institutions). Secara luas, Mead mendefinisikan pranata sebagai "tanggapan bersama dalam komunitas" atau "kebiasaan hidup komunitas". Secara lebih khusus, ia mengatakan bahwa, "keseluruhan tindakan komunitas tertuju pada individu berdasarkan keadaan tertentu menurut cara yang sama. Berdasarkan keadaan itu pula, terdapat respon yang sama di pihak komunitas. Proses ini kita sebut "pembentukan pranata". Kita membawa sekumpulan sikap yang teroganisir ini ke dekat kita, dan sikap itu membantu mengendalikan tindakan kita, sebagian besar melalui keakuan (me).

Pendidikan adalah proses internalisasi kebiasaan bersama komunitas ke dalam diri aktor. Pendidikan adalah proses yang esensial karena menurut pandangan Mead, aktor tidak mempunyai diri dan belum menjadi anggota komunitas sesungguhnya hingga mereka mampu menanggapi diri mereka sendiri seperti yang dilakukan komunitas yang lebih luas. Untuk berbuat demikian, aktor harus menginternalisasikan sikap bersama komunitas. Menurut Mead, pranata sosial seharusnya hanya menetapkan apa yang sebaiknya dilakukan individu dalam pengertian yang sangat luas dan umum saja, dan seharusnya menyediakan ruang yang cukup bagi individualitas dan kreativitas. Di sini Mead menunjukkan konsep pranata sosial yang sangat modern baik sebagai pemaksa individu maupun sebagai yang memungkinkan mereka untuk menjadi individu yang kreatif (George Ritzer, 2007: 287288).

Peneliti menggunakan teori ini karena peneliti melihat bahwa di dalam komunitas hidup sehat Herbalife sebenarnya terdapat tujuan / harapan pribadi yang mereka inginkan, yaitu "hidup sehat" namun tujuan itu kadang terbentur oleh rasa malas dalam diri sendiri dan bahkan kadang- 
kadang tidak didukung oleh orang terdekat seperti keluarga dan teman sendiri. Ketika muncul "rasa lelah" untuk tetap konsisten hidup sehat dalam diri, di situ lah komunitas sangat berperan untuk saling mengingatkan dan memotivasi kembali menerapkan hidup sehat.

Dengan menggunakan teori ini, peneliti ingin mengetahui bagaimana komunitas hidup sehat Herbalife dapat mengubah atau membentuk pola perilaku hidup sehat para anggotanya. Peneliti ingin mengetahui bagaimana diri (self) membangun pikiran atau konsep mengenai perilaku hidup sehat (mind) melalui masyarakat (society) yang mana masyarakat memiliki peran penting dalam membentuk pikiran dan diri serta memengaruhi mereka pada tingkat kemasyarakatan yang lebih khusus, yakni kebiasaan hidup komunitas.

Peneliti juga ingin mengetahui dalam pikiran para anggota yang berada di dalam komunitas hidup sehat Herbalife tersebut, batasan-batasan apa saja yang boleh dilakukan dan tidak boleh dilakukan oleh para anggota mengenai pola perilaku hidup sehat di Klub Sehat Ersanddi Jakarta.

\subsection{Studi Fenomenologi}

Pemikiran Alfred Schutz mengenai fenomenologi adalah bagaimana memahami tindakan sosial melalui penafsiran. Proses penafsiran dapat digunakan untuk memperjelas atau memeriksa makna yang sesungguhnya, sehingga dapat memberikan konsep kepekaan yang implisit. Manusia merekontruksi makna diluar arus utama pengalaman melalui proses tipikasi. Hubungan antar manusia pun diorganisasi melalui proses ini atau biasa disebut stock of knowlegde. Jadi kumpulan pengetahuan memiliki kegunaan praktis dari dunia itu sendiri, bukan sekedar pengetahuan tentang dunia. (Kuswarno, 2009: 18).

Fenomenologi sebagai disiplin ilmu adalah mempelajari strukur pengalaman dan kesadaran. Secara harfiah, fenomenologi adalah studi yang mempelajari, penampakan, segala yang muncul dalam pengalaman kita, cara kita mengalami sesuatu, dan makna yang kita miliki dalam pengalaman kita. Atau pengalaman sadar dari sudut pandang orang pertama (yang mengalaminya secara langsung). (Kuswarno, 2009: 22)

Secara keseluruhan Schutz memusatkan perhatian pada hubungan dialektika antara cara individu membangun realitas sosial dan realitas kultural yang mereka warisi dari para pendahulu mereka dalam dunia sosial. (Ritzer \& Goodman, 2004: 94-95)

Dalam pandangan Schutz, manusia adalah makhluk sosial, sehingga kesadaran akan dunia kehidupan sehari-hari adalah kesadaran sosial. Manusia dituntut untuk saling memahami satu sama lain, dan bertindak dalam kenyataan yang sama. Sehingga ada penerimaan timbal balik, pemahaman atas dasar pengalaman bersama dan tipikasi atas dunia bersama. Melalui tipikasi inilah manusia belajar menyesuaikan diri ke dalam dunia yang lebih luas, dengan juga melihat diri kita sendiri sebagai orang yang memainkan peran dalam situasi tipikal. Jadi, dalam kehidupan totalitas masyarakat, setiap individu menggunakan simbol-simbol yang telah diwariskan kepadanya, untuk memberi makna pada tingkah lakunya sendiri. Makna tersebut terbentuk dalam dunia sosial para aktor berupa sebuah "kesamaan" dan "kebersamaan" (Kuswarno, 2009: 110). Sehingga, sebuah makna disebut sebagai intersubjektif.

Inti pemikiran Schutz adalah bagaimana memahami tindakan sosial melalui penafsiran. Dimana tindakansosial merupakan tindakan yang berorientasi pada perilaku orang atau orang lain pada masa lalu, sekarang dan akan datang. Proses penafsiran dapat digunakan untuk memperjelas atau memeriksa makna yang sesungguhnya, sehingga dapat memberikan konsep kepekaan yang implisit. Dengan kata lain, mendasarkan tindakan sosial pada pengalaman, makna, dan kesadaran. Manusia mengkonstruksi makna di luar arus utama pengalaman melalui proses "tipikasi". Untuk menggambarkan keseluruhan tindakan seseorang, Schutz mengelompokkannya dalam dua fase, yaitu: (1). In-order-to-motive (Um-zu-Motiv), yaitu motif yang merujuk pada tindakan di masa yang akan datang. Dimana tindakan yang dilakukan oleh seseorang pasti memiliki tujuan yang telah ditetapkan, dan (2). Because motives (Weil Motiv), yaitu tindakan yang merujuk pada masa lalu. Dimana tindakan yang dilakukan oleh seseorang pasti memiliki alasan dari masa lalu ketika ia melakukannya.

Dari tradisi interaksionisme simbolik, gagasan yang di ambil Schutz adalah 'definisi situasi' yang dirumuskan W.I Thomas: 'individu bertindak berdasarkan makna yang diperolehnya melalui interpretasi' (Samuel, 2012 dalam Sobur, 2014: 52). Schutz setuju bahwa definisi situasi merupakan landasan dari kehidupan sosial yang dipelajari aktor berdasarkan pengalaman masa lalunya. Namun, 
hal ini tidak lantas berarti bahwa defines situasi merupakan hal yang statis. Dalam interaksi yang dilakukan pada masa kini, definisi situasi terus menerus diubah oleh sang aktor. Gagasan interaksionisme simbolik lainnya yang diterima Schutz adalah role taking ('pengambilan peran'). Schutz beranggapan bahwa hanya melalui proses pengambilan peran saja para aktor bisa saling memahami peranan dan mengkategorikan sesamanya. (Sobur, 2014: 52)

\subsection{Komunitas}

Komunitas berasal dari bahasa latin communitas yang berarti kesamaan kemudian dapat diturunkan dari communis yang berarti sama, public, dibagi oleh semua atau banyak. Yang disebut sama dalam hal ini bisa berarti hobi, tipe, sifat, pikiran, visi bahkan ideologi. Hubungan komunitas meng-upgrade kualitas dari tiap-tiap anggota komunitas aktif. Pengetahuan yang dishare dalam bentuk tips, saran, petunjuk dan obrolan informal dapat diserap secara baik karena dibawakan oleh teman satu visi dengan menggunakan bahasa yang sederhana. Oleh karenanya, komunitas bisa menjadi solusi bagi pencerdasan kehidupan modern. Komunitas adalah sebuah kelompok sosial dari beberapa organisme berbagai lingkungan, umumnya memiliki ketertarikan dan habitat yang sama. Dalam komunitas manusia, individu-individu di dalamnya dapat memiliki maksud, kepercayaan, sumber daya, preferensi, kebutuhan, risiko dan sejumlah kondisi lain yang serupa.

Komunitas adalah sekelompok orang yang saling peduli satu sama lain lebih dari yang seharusnya, di mana dalam sebuah komunitas terjadi relasi pribadi yang erat antar para anggota komunitas tersebut karena adanya kesamaan interest atau values (Kertajaya, 2008: 182). Proses pembentukannya bersifat horisontal karena dilakukan oleh individu-individu yang kedudukannya setara.

Komunitas adalah sebuah identifikasi dan interaksi sosial yang dibangun dengan berbagai dimensi kebutuhan fungsional (Soenarno, 2002 dalam Kertajaya, 2008: 182). Kekuatan pengikat suatu komunitas, terutama adalah kepentingan bersama dalam memenuhi kebutuhan kehidupan sosialnya yang biasanya didasarkan atas kesamaan latar belakang budaya, ideologi, sosial-ekonomi. Secara fisik suatu komunitas biasanya diikat oleh batas lokasi atau wilayah geografis. Masing-masing komunitas, karenanya akan memiliki cara dan mekanisme yang berbeda dalam menanggapi atau menyikapi keterbatasan yang dihadapinya serta mengembangkan kemampuan kelompoknya.

\subsection{Perilaku Hidup Sehat}

Menurut Becker, konsep perilaku sehat merupakan pengembangan dari konsep perilaku yang dikembangkan Bloom. Becker menguraikan perilaku kesehatan menjadi tiga domain, yakni pengetahuan kesehatan (health knowledge), sikap terhadap kesehatan (health attitude) dan praktik kesehatan (health practice). Hal ini berguna untuk mengukur seberapa besar tingkat perilaku kesehatan individu yang menjadi unit analisis penelitian. Becker mengklasifikasikan perilaku kesehatan menjadi tiga dimensi: (1). Pengetahuan kesehatan, yaitu pengetahuan tentang kesehatan mencakup apa yang diketahui oleh seseorang terhadap cara-cara memelihara kesehatan, seperti pengetahuan tentang penyakit menular, pengetahuan tentang faktor-faktor yang terkait dan atau mempengaruhi kesehatan, pengetahuan tentang fasilitas pelayanan kesehatan, dan pengetahuan untuk menghindari kecelakaan, (2). Sikap, yaitu sikap terhadap kesehatan adalah pendapat atau penilaian seseorang terhadap hal - hal yang berkaitan dengan pemeliharaan kesehatan, seperti sikap terhadap penyakit menular dan tidak menular, sikap terhadap faktor-faktor yang terkait dan atau memengaruhi kesehatan, sikap tentang fasilitas pelayanan kesehatan, dan sikap untuk menghindari kecelakaan, dan (3). Praktek kesehatan, yaitu praktek kesehatan untuk hidup sehat adalah semua kegiatan atau aktivitas orang dalam rangka memelihara kesehatan, seperti tindakan terhadap penyakit menular dan tidak menular, tindakan terhadap faktor-faktor yang terkait dan atau memengaruhi kesehatan, tindakan tentang fasilitas pelayanan kesehatan, dan tindakan untuk menghindari kecelakaan.

Secara singkat dapat disimpulkan bahwa perilaku kesehatan adalah semua aktivitas atau kegiatan seseorang, baik yang dapat diamati (observable) maupun yang tidak dapat diamati (unobservable), yang berkaitan dengan pemeliharaan dan peningkatan kesehatan. Pemeliharaan kesehatan ini mencakup mencegah atau melindungi diri dari penyakit dan masalah kesehatan lain, meningkatkan kesehatan, dan mencari penyembuhan apabila sakit atau terkena masalah kesehatan (eprints.uny.ac.id, 2017). 


\section{Metode Penelitian}

Paradigma yang digunakan dalam penelitian ini adalah paradigma konstruktivis. Peneliti ingin me-rekonstruksi sebuah pola perilaku hubungan antara manusia dengan sebuah studi fenomenologis. Konstruktivis meyakini bahwa untuk memahami dunia makna ini orang harus menginterpretasikannya dan peneliti harus menjelaskan proses-proses pembentukan makna dan menerangkan ihwal serta bagaimana makna-makna tersebut terkandung dalam bahasa dan tindakan para aktor sosial. (Denzin \& Lincoln, 2009: 146).

Pelaksanaan penelitian ini menggunakan metodologi atau pendekatan kualitatif, karena tujuannya adalah untuk mendesripsikan dan menggambarkan apa adanya mengenai suatu variabel, gejala, keadaan atau fenomena sosial tertentu. Dalam hal ini guna menganalisis data yang diperoleh secara mendalam dan menyeluruh, dengan harapan dapat diketahui sejauh mana peran komunitas dalam membentuk konsep diri individu-individu yang ada dalam kelompok dalam membangun kualitas hidup sehat.

Studi fenomenologi digunakan untuk menggambarkan fenomena gaya hidup sehat dalam suatu komunitas. Moleong menjelaskan bahwa fenomenologi tidak berasumsi bahwa peneliti mengetahui arti sesuatu bagi orang-orang yang sedang diteliti oleh mereka. Inkuiri fenomenologis memulai dengan diam. Diam merupakan tindakan untuk menangkap pengertian sesuatu yang sedang diteliti. Mereka beruaha untuk masuk ke dalam dunia konseptual para subjek yang ditelitinya sedemikian rupa sehingga mereka mengerti apa dan bagaimana suatu pengertian yang dikembangkan oleh mereka di sekitar peristiwa dalam kehidupan sehari-hari (Moleong, 2000:9 dalam Mulyana, 2014:91)

Informan dalam penelitian ini berjumlah 7 orang. Pemilihan informan sebagai sumber data dalam penelitian ini adalah berdasarkan pada asas subyek yang menguasai permasalahan, memiliki data, dan bersedia memberikan imformasi lengkap dan akurat. Informan pertama sebagai informan kunci merupakan orang yang paham bagaimana konsep diri hidup sehat anggota komunitas Herbalife Klub Sehat Ersanddi pada saat sebelum dan sesudah mengikuti program hidup sehat dan sebagai coach yang memandu dan mengarahkan member untuk memulai hidup sehat. Ketujuh informan tersebut dipilih dengan alasan karena mereka memiliki latar belakang permasalahan yang berbeda sehingga menarik untuk diteliti.

Sumber data penelitian diambil dari data primer (wawancara mendalam dan observasi) dan data sekunder (dokumen/arsip yang diperoleh sebagai data pendukung). Tehnik pengumpulan data yang dipakai adalah observasi dan wawancara mendalam. Dalam menguji kredibilitas hasil data, peneliti menggunakan teknik triangulasi yang digunakan peneliti adalah triangulasi sumber dan triangulasi metode. Triangulasi sumber yakni dengan memeriksa dan membandingkan data yang telah diperoleh dari satu sumber data dengan beberapa data lain. Data yang dimaksud adalah data dari informan yang akan diperiksa melalui informan satu dengan informan lainnya. Triangulasi metode adalah mengumpulkan data yang diperoleh dari observasi dan wawancara mendalam terhadap informan.

\section{Hasil Dan Pembahasan}

\subsection{Makna Hidup Sehat Anggota Komunitas Herbalife Klub Sehat Ersanddi}

Berdasarkan hasil penelitian, dari ketujuh informan memiliki makna hidup sehat yang berbeda-beda satu sama lain, yaitu : memiliki tubuh ideal; seimbang jasmani dan rohani; dapat melaksanakan aktifitas sehari-hari tanpa hambatan atau kendala; menjaga pola makan dan olahraga teratur; bisa menjalankan aktivitas ibadah dan kegiatan sehari-hari tanpa hambatan apapun; hidup sehat berimbang hak akal atau fikiran; hak tubuh atau fisik dan hak bathin psikis atau jiwa ruh. Semua informan menyatakan bahwa makna sehat itu dilihat dari penampilan namun tidak ada patokan pasti dari penampilan tersebut harus bertubuh ramping, dan kurus. Mereka menyatakan yang paling penting dari sehat adalah dapat menikmati hidup dan beribadah kepada sang Pencipta tanpa hambatan apapun.

Salah satu informan Siti Alawiyah mengungkapkan bahwa komunitas ini mampu merubah pandangannya mengenai makna hidup sehat:

"Iyaa bisa di katakan mampu merubah pandangan saya menngenai hidup sehat.. yang awalnya saya berpikir kenapa sih harus merubah gaya hidup.. merubah pola makan.. kok sepertinya 
tidak menikmati hidup banget yaa.. hidup itu harus di nikmati dengan makan sesuka hati kita.. makan apa yang kita mau.. tanpa memikirkan asupan nutrisi dan sebagainya.. ngapain juga olahraga.. gw dah cukup capek dengan rutinitas sebagai IRT yaa anggaplah itu olahraga. Ternyataaa pandangan itu salah.. dalam komunitas ini kita belajar bagaimana cara menghargai hidup kita.. bagaimana kita dapat menikmati hidup kita lebih lama lagi.. hidup sehat harus dimulai sedini mungkin agar dampaknya yang akan kita rasakan untuk jangka panjang supaya kita bisa menikmati hidup kita lebih lama lagi tanpa adanya gangguan penyakit di hari tua kelak. Menghargai hidup kita dengan merubah gaya hidup.. merubah pola makan..itulah wujud bersyukur kita di anugerahi tubuh yang sehat oleh Allah SWT dan kita wajib menjaganya."

Banyak faktor yang memengaruhi gaya hidup, salah satunya adalah konsep diri. Konsep diri merupakan merupakan salah satu tema yang ada di dalam Teori Interaksi Simbolik. Konsep diri ketujuh informan ini tidak terbentuk dengan sendirinya. Dalam penelitian ini, berdasarkan hasil penelitian pembentukan konsep diri ketujuh informan yang merupakan subyek dari penelitian ini dibagi menjadi dua yaitu primer dan sekunder. Yang termasuk kedalam primer adalah significant others yaitu orang tua, keluarga, dan teman, dan yang temasuk kedalam sekunder adalah reference group yaitu coach atau personal consultant Klub Sehat Herbalife.

Berdasarkan hasil penelitian, ketujuh informan yang merupakan anggota komunitas Herbalife Klub Sehat Ersanddi, makna hidup sehat yang mereka miliki juga terpengaruh oleh lingkungan sosial dan budaya yang dilihat melalui interaksi yang mereka lakukan dengan orang -orang disekitarnya seperti significant others dan reference group. Significant others adalah orang yang dekat dengan ketujuh informan seperti orang tua, keluarga, dan teman. Sedangkan reference group merupakan kelompok yang secara emosional mengikat kita.

Ketujuh informan menyatakan bahwa makna hidup sehat yang mereka miliki sama sama terpengaruh dari significant others, dan reference group terutama sangat berpengaruh dalam membentuk makna hidup sehat. Informan Dinny menyatakan bahwa selain dipengaruhi oleh suami dan teman dekatnya yang masuk ke dalam significant others, dia juga mendapatkan pengaruh dari kelompok yang dia ikuti, yaitu komunitas Herbalife Klub Sehat Ersanddi yang secara tidak langsung mempengaruhi bagaimana makna hidup sehat yang dia miliki. Melalui significant others dan reference group ketujuh informan dapat mengetahui lingkungan sosial dan budaya yang ada di masyarakat yang akhirnya membentuk bagaimana makna hidup sehat yang mereka miliki.

Semua orang mendambakan hidup sehat. Pengertian hidup sehat dapat didefinisikan sebagai hidup tanpa ganguan masalah yang bersifat fisik maupun non fisik. Gangguan fisik berupa penyakitpenyakit yang menyerang tubuh dan fisik seseorang. Sementara non fisik menyangkut kesehatan kondisi jiwa, hati dan pikiran seseorang. Artinya, kesehatan meliputi unsur jasmani dan rohani. Berikut model konstruksi makna pada komunitas Herbalife Klub Sehat Ersanddi Jakarta:

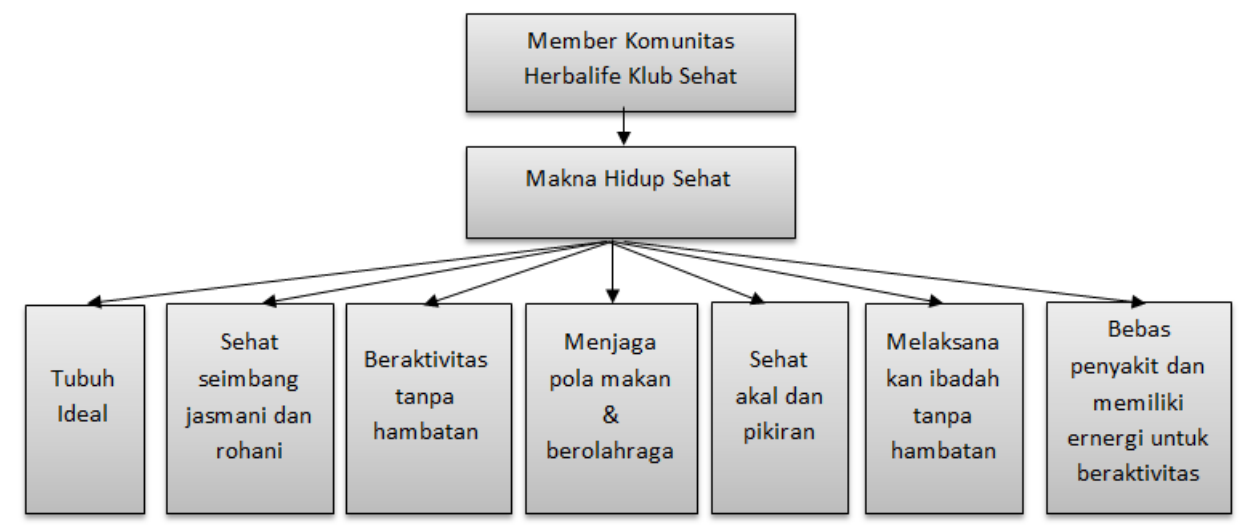

Gambar. 1. Gambar Model Kontruktif Makna Anggota Komunitas Klub Sehat Ersanddi

\subsection{Interaksi Simbolik dalam Pembentukan Gaya Hidup Sehat}


Teori interaksi simbolik didasarkan pada ide-ide mengenai diri dan hubungannya dengan masyarakat. Orang tergerak untuk bertindak berdasarkan makna yang diberikannya pada orang, benda, dan peristiwa. Makna-makna ini diciptakan dalam bahasa, yang digunakan orang baik untuk berkomunikasi dengan orang lain maupun dengan dirinya sendiri, atau pikiran pribadinya. Bahasa memungkinkan orang untuk mengembangakan perasaan mengenai diri dan untuk berinteraksi dengan orang lainnya dalam sebuah komunitas.

Pada bagian ini dibahas lebih lanjut mengenai temuan-temuan lapangan yang akan dihubungkan dengan teori teori. Konsep diri meliputi pikiran dan perasaan seseorang tentang dirinya sendiri. Dalam penelitian ini diketahui bahwa untuk memahami konsep diri, para informan melakukannya melalui beberapa tahap. Pada tahap awal, para informan memaknai bahwa hidup sehat dan memiliki berat badan ideal itu sebagai sesuatu yang sangat sulit. Pandangan seperti itu dimiliki sebelum mereka bergabung dengan komunitas Herbalife Klub Sehat Ersanddi. Tahap selanjutnya, Ketujuh informan mulai mencoba pola hidup sehat dan melakukan olahraga dengan cara bergabung dengan komunitas Herbalife Klub Sehat Ersanddi. Mereka memandang bahwa Active Healthy Life Style atau hidup sehat dan aktif berolahraga itu cukup berat dilakukan oleh kebanyakan orang. Hal ini karena mereka beranggapan bahwa hidup sehat identik dengan diet yang menyiksa diri tidak boleh makan enak dan sesuka hati sehingga mereka beranggapan sangat tidak bisa menikmati hidup. Pada tahap ketiga mulai terjadi proses pembentukan konsep diri anggota komunitas Herbalife Klub Sehat Ersanddi.

Mead menjelaskan terdapat tiga konsep penting dalam teori interaksi simbolik, yaitu pikiran (mind), diri (self), dan masyarakat (society). Disini penulis menganalisis fenomena ini dengan tiga konsep penting mead dalam interaksi simbolik sebagai berikut: (1). Pikiran (mind), Pikiran adalah kemampuan untuk menggunakan simbol yang mempunyai makna sosial yang sama dan pengembangannya melalui cara berinteraksi dengan orang lain. Gaya hidup sehat menurut Anne adalah suatu gaya hidup dengan memperhatikan faktor-faktor tertentu yang mempengaruhi kesehatan, antara lain makanan dan olahraga. Selain itu gaya hidup seseorang juga mempengaruhi tingkat kesehatannya (Anne dalam Situngkir: 2012:9). Hal tersebut sesuai dengan pengertian gaya hidup sehat menurut ketujuh informan, menurut ketujuh informan definisi gaya hidup sehat adalah dengan berolahraga dan mengatur pola makan. Bahkan terdapat satu informan yang menyatakan bahwa definisi gaya hidup sehat bukan hanya berolahraga dan mengatur pola makan sehat saja, namun dengan mengatur pola hidup juga. Pemahaman mengenai gaya hidup sehat tersebut dipengaruhi oleh orang-orang disekitar kelima informan tersebut seperti significant others dan reference group. (2). Diri (self) Menurut Mead dalam (Morissan 2013:145), 'diri' mewakili dua sisi yang masing-masing memiliki tugas penting, yaitu diri yang mewakili saya sebagai subjek (I) dan saya sebagai objek $(\mathrm{Me})$. Saya subjek adalah tenaga pendorong untuk melakukan tindakan, sedangkan konsep diri atau saya objek memberikan arah dan panduan. Ketika diri sebagai subjek contohnya, Ketujuh informan yang mementingkan gaya hidup sehat ini membuat mereka rutin melakukan olahraga dan mengubah pola makan. Dalam seminggu mereka berolahraga minimal dua hingga tiga kali. Termasuk melakukan kegiatan rutin sarapan sehat bersama setiap pagi di Klub Sehat Ersanddi, sehingga memberikan efek terhadap perubahan tubuh menjadi lebih sehat dan turun berat badan maupun kadar lemaknya. Bagi Mead, diri berkembang dari sebuah jenis pengambilan peran yang khusus-maksudnya, membayangkan bagaimana kita dilihat oleh orang lain. Meminjam konsep yang berasal dari seseorang sosiologis harles Cooley pada tahun 1912, Mead menyebutkan hal tersebut sebagai cermin diri (looking-glass-self), atau kemampuan kita untuk melihat diri kita sendiri dalam pantulan dari padangan orang lain. Selanjutnya adalah self atau diri dari ketujuh anggota komunitas di Klub Sehat Ersanddi. Dari pembahasan diatas dapat terlihat bahwa ketujuh anggota komunitas tersebut mendapatkan pengaruh mengenai gaya hidup sehat dari significant others dan reference group. Arahan dan pengaruh yang diberikan orang tua, keluarga, dan teman yang masuk kedalam significant others dan pengaruh yang diberikan oleh coach atau konsultan Klub Sehat Herbalife yang masuk ke dalam reference group mempengaruhi ketujuh informan yang pada akhinya membuat ketujuh informan tersebut melakukan gaya hidup yang sehat. Ketika diri sebagai objek, konsep diri memberikan arahan kepada informan untuk melakukan perubahan mengenai perilaku atau kebiasaan hidup tidak sehat menjadi pola hidup sehat. Informan memersepsi bentuk tubuh yang di peroleh karena perubahan gaya hidup sehat tersebut membuat dirinya merasa bangga dan senang karena bentuk tubuhnya menjadi ideal dan merepresentasikan dirinya sebagai orang yang berhasil 
menerapkan pola hidup sehat dan rutin melakukan olahraga untuk mendapatkan kepuasan hati yakni hidup sehat dan langsing dan menularkan kebiasaannya pada banyak orang, dan (3). Masyarakat (society), Masyarakat terdiri atas jaringan interaksi sosial tempat anggota masyarakat memberikan makna terhadap tindakan mereka sendiri dan tindakan orang lain dengan menggunakan simbol. Contohnya, informan mempersepsi citra dirinya sebagai orang yang berhasil menerapkan pola hidup sehat dan merasa bangga dengan hal itu. Hal tersebut mendorongnya untuk memotivasi orang-orang terutama wanita untuk melakukan gaya hidup sehat seperti mereka. Secara tidak langsung, anggota komunitas ini berperan mengubah persepsi masyarakat bahwa hidup sehat itu mudah dan menyenangkan serta tidak menyiksa karena memiliki pemahaman mengenai konsep hidup sehat itu dengan mengubah pola makan dan gaya hidup serta cerdas memilih makanan yang masuk ke dalam tubuhnya.

Pemikiran Mead mengenai orang lain secara khusus (particular others) merujuk pada individu-individu dalam masyarakat yang signifikan bagi kita. Orang-orang tersebut biasanya adalah keluarga, teman dan kolega di tempat kerja. Kita melihat orang lain secara khusus tersebut untuk mendapatkan rasa penerimaan sosial. Yang termasuk kedalam particular others dari kelima informan ini adalah keluarga, orang tua, dan teman, atau bisa disebut juga significant others.

Pengaruh dari orang-orang tersebut membentuk bagaimana gaya hidup sehat yang mereka jalani. Yang kedua adalah generalized others atau orang lain secara umum. Yang termasuk dari generalized others adalah coach atau konsultan Klub sehat Herbalife. Menurut salah satu informan yaitu Windha dengan melalui coach atau personal consultan salah satu informan bisa mengetahui bagaimana aturan-aturan yang ada di komunitas Klub Sehat Ersanddi yang pada akhirnya mempengaruhi bagaimana gaya hidup sehat yang Windha jalani. Jadi mind, self, dan society memengaruhi bagaimana konsep diri komunitas Herbalife Klub Sehat Ersanddi mengenai pola hidup sehat.

\subsection{Gaya Hidup Sehat yang Dijalani}

Gaya hidup menurut Plumer (1983) adalah cara hidup individu yang diidentifikasikan oleh bagaimana orang menghabiskan waktu mereka (aktivitas), apa yang mereka anggap penting dalam hidupnya (keterikatan) dan apa yang mereka pikirkan tentang dunia sekitarnya (Plummer dalam Kaparang, 2013:3).

Berdasarkan hasil dari penelitian, anggota komunitas Herbalife di Klub Sehat Ersanddi memiliki gaya hidup sehat, gaya hidup sehat yang mereka jalani adalah dengan berolahraga, mengatur pola makan dan makan makanan bergizi, dan mengatur pola hidup. Melihat penjelasan Plummer mengenai gaya hidup, dengan melakukan olahraga, mengatur pola makan dan makan makanan bergizi, dan mengatur pola hidup, anggota komunitas Herbalife di Klub Sehat Ersanddi tersebut ingin memperlihatkan bahwa gaya hidup yang mereka jalani adalah gaya hidup yang sehat.

Ketujuh informan yang merupakan anggota komunitas Herbalife di Klub Sehat Ersanddi memiliki gaya hidup sehat yang berbeda-beda satu sama lain. Namun terdapat kesamaan gaya hidup sehat yang dilakukan dari kelima informan tersebut yaitu dengan cara merubah pola makan dan berolahraga. Hal tersebut sesuai dengan definisi gaya hidup sehat menurut Anne, yaitu suatu gaya hidup yang memerhatikan faktor-faktor tertentu yang mempengaruhi kesehatan, antara lain makanan dan olahraga (Anne dalam Situngkir:2012:9). Jadi gaya hidup yang dilakukan oleh para anggota komunitas tersebut sudah termasuk kedalam gaya hidup yang sehat, karena melibatkan kegiatankegiatan yang mempengaruhi kesehatan mereka sendiri. Menurut tabloid, gaya hidup sehat memberikan kondisi positif bagi diri sendiri dan lingkungan (Mister dalam Situngkir, 2012:10).

Dampak positif yang didapatkan oleh anggota komunitas tersebut adalah membuat tubuh menjadi lebih sehat dan bugar, berkurangnya keluhan penyakit yang mereka alami, menghilangkan stress, dan mempercantik diri dengan menjadi lebih langsing dan sehat. Selain itu, dampak positif yang didapatkan dengan melakukan gaya hidup yang sehat adalah membuat anggota komunitas tersebut menarik dimata orang lain karena dapat memiliki postur tubuh yang ideal. 


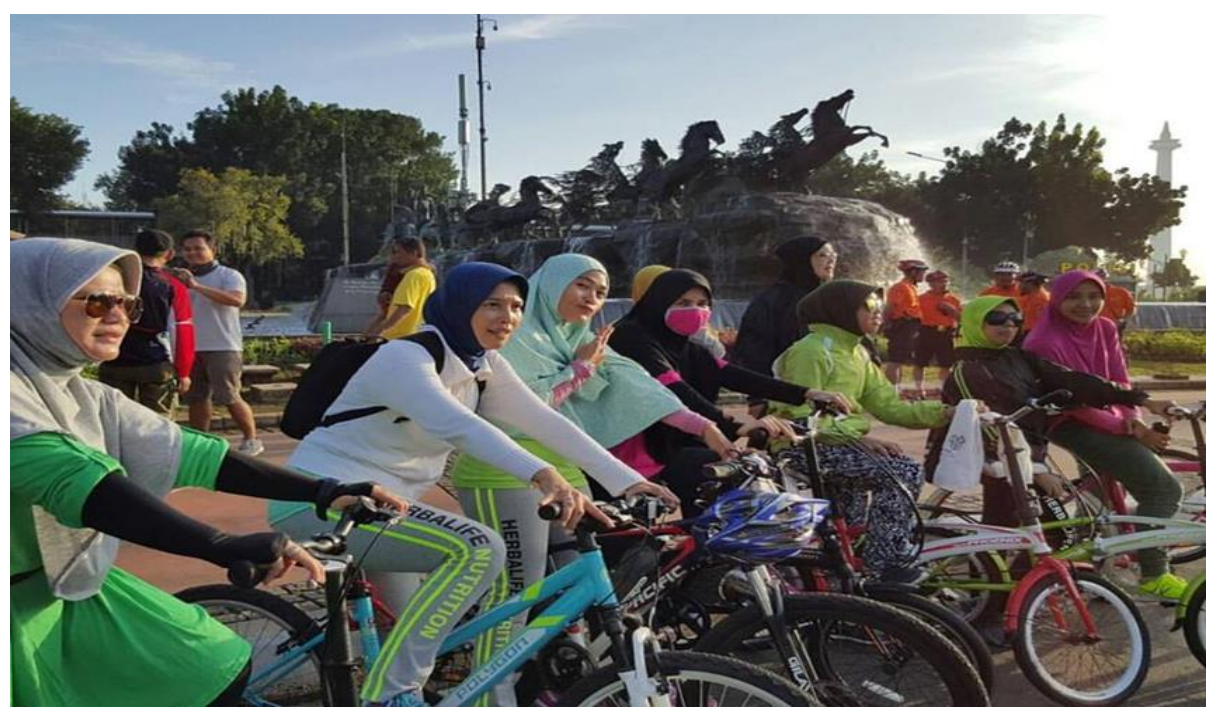

\section{Gambar 2. Kegiatan Fun bike komunitas Herbalife Klub Sehat Ersanddi}

\section{Simpulan Dan Saran \\ 5.1. Simpulan}

Berdasarkan paparan di atas, dapat disimpulkan bahwa: (1). Motif member atau anggota komunitas Herbalife Klub Sehat Ersanddi mengikuti program hidup sehat karena ingin menurunkan berat badan dan ingin sehat jasmani, (2). Makna hidup sehat anggota komunitas Herbalife Klub Sehat Ersanddi adalah : memiliki tubuh ideal: seimbang seimbang jasmani dan rohani: dapat melaksanakan aktifitas sehari-hari tanpa hambatan atau kendala; menjaga pola makan dan olahraga teratur; bisa menjalankan aktivitas ibadah dan kegiatan sehari-hari tanpa hambatan apapun; hidup sehat berimbang hak akal atau fikiran, hak tubuh atau fisik dan hak bathin psikis atau jiwa ruhi, (3). Mind, memaknai bahwa hidup sehat dan memiliki berat badan ideal itu sebagai sesuatu yang sangat sulit. Self, yakni diri melakukan perubahan perilaku atau kebiasaan, dan memberikan arahan untuk melakukan tindakan mengenai perubahan perilaku atau kebiasaan hidup tidak sehat menjadi pola hidup sehat. Society, mempresentasikan dirinya sebagai orang yang berhasil menerapkan pola hidup sehat dan merasa bangga dengan hal itu. Hal tersebut mendorongnya untuk memotivasi orang-orang terutama wanita untuk melakukan gaya hidup sehat seperti mereka dan menularkan kebiasaannya pada banyak orang. Secara tidak langsung, komunitas klub sehat Ersanddi berperan sebagai agen perubahan dalam hal mengubah persepsi masyarakat bahwa hidup sehat itu mudah dan menyenangkan serta tidak menyiksa, sehingga membuat lingkungan sekitar tertarik untuk menerapkan pola hidup sehat, dan (4). Kedua faktor yang memengaruhi terbentuknya konstruksi makna kualitas hidup sehat anggota komunitas Herbalife Klub Sehat Ersanddi adalah Keluarga (significant others) dan kelompok rujukan (reference group). Keluarga berperan penting dalam pembentukan konsep diri anggota komunitas Herbalife Klub Sehat Ersanddi karena keluarga merupakan pertama kali yang menemukan konsep diri anggota komunitas Herbalife Klub Sehat Ersanddi dan ini mempengaruhi prilakunya di masa depan. dan kelompok rujukan (reference group) merupakan suatu kelompok yang memiliki fungsi sebagai menciptakan norma dari tingkah laku dan mengevaluasi kayakinan para anggota komunitas Herbalife Klub Sehat Ersanddi.

\subsection{Saran}

Berdasarkan hasil penelitian dan merujuk pada manfaat penelitian, peneliti memberikan saran sebagai berikut : (1). Perlu diingat bahwa bagaimanapun hidup sehat sangat penting. Lingkungan masyarakat hendaknya lebih terbuka terhadap informasi-informasi baru atau melek informasi mengenai manfaat hidup sehat agar lebih memahami dan menciptakan lingkungan yang nyaman atau kondusif terhadap pola hidup sehat, (2). Pola hidup sehat harus diterapkan oleh masyarakat mulai dini agar di masa depan memiliki kualitas hidup yang lebih baik, terhindar dari berbagai macam penyakit degerenatif yang semakin berkembang cepat dewasa ini. Kesadaran dini mengenai konsep diri tentang kesehatan perlu 
ditumbuhkan oleh orang tua, lingkungan sekitar maupun pemerintah, (3). Untuk Klub Sehat Ersanddi sebagai sarana atau wadah interaksi komunitas Herbalife diharapkan dapat terus memberikan motivasi dan dukungan secara berkesinambungan kepada para membernya untuk dapat terus melaksanakan pola hidup sehat melalui kegiatan-kegiatan yang dapat menunjang program kesehatan masyarakat pada umumnya bukan hanya di kalangan komunitas saja, dan (4). Kepada peneliti selanjutnya, Penelitian ini lebih fokus pada konsep diri hidup sehat dengan menggali data beberapa aspek konsep diri, disarankan untuk penelitian selanjutnya untuk lebih menggali hal menarik lainnya dan diharapkan peneliti selanjutnya agar lebih memaksimalkan teknik penelitian, mendeskripsikan faktor-faktor lain yang belum terungkap secara lebih mendetail dalam penelitian ini.

\section{Daftar Pustaka}

1) Andre Hardjana. 2000. Audit komunikasi Teori dan Praktek. Jakarta: Grasindo

2) Anwar Arifin, 1994. Strategi Komunikasi: sebuah Pengantar Ringkas. Bandung: Armico

3) Elvinaro Ardianto. 2010. Metodologi Penelitian Untuk Public Relations, Kualitatif dan Kuantitatif. Bandung. Simbiosa Rekatama Media

4) Kuswarno, Engkus. 2009. Metode Penelitian Komunikasi: Fenomenologi, Konsepsi, Pedoman dan Contoh Penelitiannya, Widya Padjajaran, Perpustakaan Pusat UII

5) Morissan. 2013. Teori Komunikasi: Individu Hingga Massa. Edisi Pertama. Jakarta: Kencana

6) Mulyana, Deddy. 2008. Ilmu Komunikasi Suatu Pengantar. Bandung: PT Remaja Rosdakarya.

7) Ritzer George \& Goodman, Douglas J, 2007. Teori Sosiologi Modern. Edisi Ketujuh. Jakarta: Kencana

8) Sobur. Alex. 2014. Filsafat Komunikasi: Tradisi dan Metode Fenomenologi. Bandung: PT Remaja Rosdakarya

Internet:

9) Anne. 2010. Gaya Hidup Sehat.

10) http://repository.usu.ac.id/bitstream/123456789/33995/4/ Chapter20II.pdf diakses tanggal 19 Februari 2017

11) Ari. 2005. Pola Perilaku dan Gaya Hidup.

12) http://repository.usu.ac.id/bitstream/123456789/33995/Chapter\%20II.pdf diakses tanggal 19 Februari 2017, Kertajaya, Hermawan. 2008. Komunitas.

13) http://digilib.unila.ac.id/272/8/Bab\%20II.pdf diakses tanggal 12 Januari 2017, Mister. 2008. Gaya Hidup Sehat.

14) http://repository.usu.ac.id/bitstream/123456789/33995/Chapter\% 20II.pdf diakses tanggal 19 Februari 2017 